\title{
MARIÁNSKÁ ÚCTA A NÁSTĚNNÉ MALBY V KOSTELE NEPOSKVRNĚNÉHO POČETÍ PANNY MARIE A SV. BERNARDINA SIENSKÉHO V OLOMOUCI NA BĚLIDLECH
}

\author{
VLADĚNA PAVLÍKOVÁ \\ Ústav pro dějiny umění, Filozofická fakulta Univerzity Karlovy \\ E-mail: vladenapavlikova@gmail.com
}

\begin{abstract}
Marian piety and the wall paintings at the Church of the Immaculate Conception of the Virgin Mary and St. Bernardine of Siena in Olomouc

The text deals with the mural paintings at the end of the northern and southern nave of the Church of the Immaculate Conception of the Virgin Mary in Olomouc. They are connected with Marian piety and its expression in the rosary. These trends were supported by the mendicant orders and spread through the influence of the FranciscanObservants. Among the Franciscans of the 15th century was the most popular version the one that was promoted by St Bernardino of Siena and his disciple St Giovanni of Capistrano, who has visited Olomouc in the fifties of the 15th century.

Keywords: Wall paintings; Olomouc; Church of the Immaculate Conception of the Virgin Mary; Rosary; the Order of Friars Minor
\end{abstract}

Olomoucký klášterní kostel, nesoucí patrocinium Neposkvrněného početí Panny Marie a sv. Bernardina Sienského, je nejstarším bernardinským klášterem v českých zemích. Františkánská observance sehrála v pohusitském období v českých zemích důležitou roli, nebot’ se stala významnou oporou katolické církve. Nebývalý rozkvět řádu s sebou přinesl nové př́ležitosti, jimiž mohli bratři čelit rané české reformaci a neúnavně vystupovat proti kacířství, což především dokládají jimi vedené polemiky. ${ }^{1}$ Řeholníci preferovali osobní kontakt se širokými vrstvami obyvatel, aktivně se zapojovali do náboženského dění, vedli náboženské diskuse při různých příležitostech, jako byly například pohřby či sbírání almužen, a soustředili se hlavně na formu kázání, kterou se snažili oslovit co nejvíce posluchačů. Významným impulsem pro rozvoj provincie byla v roce 1451 misie Jana Kapistrána, který ji zkonsolidoval a předložil novou ideovou koncepci pro další rozvoj. ${ }^{2}$

Přítomnost Jana Kapistrána v Olomouci výrazně proměnila nejen náboženský život města, ale i jeho podobu, jak dokládají staré a nové formy katolické zbožnosti. Mezi tyto devocionálie patří pochopitelně ochranné nápisy a bernardinské emblémy s trigramem $y h s$ uprostřed plamenného slunce, stejně jako odpustky, poutě a v neposlední řadě

1 Petr Elbel, Bohemia Franciscana: Františkánský rád a jeho pưsobení v českých zemích 17. a 18. století, Olomouc 2001, s. 36.

2 Kláštery, které sám založil nebo které za jeho přispění, se staly opěrnými body katolické víry. V rakousko-česko-polské provincii, kterou se Janu Kapistránovi podařilo na vídeňské kapitule dne 8 . září 1452 založit, vzniklo dvacet klášterů, v nichž působilo kolem 800 bratří, viz Petr Hlaváček, Čeští františkáni na přelomu středověku a novověku, Praha 2005, s. 26. 
i rychle se šírící kult růžencové pobožnosti, jemuž bude v tomto příspěvku věnována pozornost.

$\mathrm{Na}$ čelní stěně jižní boční lodi klášterního kostela se dochovala nástěnná malba $R$ น̊žencové Madony. [Obr. 1] Tuto malbu, odkrytou roku 1880, uvedl do literatury o deset let později Adolf Nowak. ${ }^{3}$ Nové zhodnocení a výraznější posun v ikonografii obrazu lze nalézt v krátké kapitole od Františka Bolka, ${ }^{4}$ který poprvé označil Bohorodičku jako Pannu Marii Růžencovou. Na počátku sedmdesátých let minulého století vyšel článek z pera Ivo Hlobila, ${ }^{5}$ jenž jako první zohlednil vliv kulturních, historických a sociálních vlivů na vznik nástěnné malby. Roku 2007 byla publikována rukopisná stránka s textem Declaratio brevis Corone immaculate Virginis, ${ }^{6}$ jenž je součástí konvolutu čtyř prvotisků uchovávaných ve Vědecké knihovně v Olomouci. Objevený text, napsaný čtyři roky před vznikem nástěnné malby, dobře odpovídá olomoucké malbě a vysvětluje, jak se má vyobrazení vnímat a vykládat z hlediska tehdejší mariánské zbožnosti.

\section{Růžencový obraz}

Výjev, lemovaný po obvodu motivem spletených holých větví, je rozdělený do tří horizontálních částí. Uprostřed dolní partie je situována korunovaná Assumpta oděná ve slunci s Ježíškem v náručí. [ [Obr. 2] K ústř̌ední dvojici přilétají po obou stranách dva andělé nesoucí po jedné koruně, která je zmenšenou verzí koruny Bohorodičky. Přestože je pozadí za Madonou a anděly provedeno v abstraktní zlaté barvě, jsou postavy po jejích obou stranách umístěny před jednoduché architektonické pozadí. Od něho vybíhají ke středu dvě nízké zídky, oddělující ústřední skupinu od zástupců světského a duchovního stavu. Na pravé straně se jedná o zobrazení deseti duchovních, v jejichž čele je nejblíže Madoně zobrazen klečící papež, kterého doprovází jak prelát spolu s biskupem, tak členové řádů $\mathrm{v}$ jejich charakteristickém prostém šatu. Na protější straně jsou vyobrazeni světští zástupci, mezi nimiž jsou v popředí zachyceny dvě korunované mužské postavy. V této skupině čítající celkem třináct figur jsou zastoupeny kromě mužů i čtyřri ženy a dvě děti. $\mathrm{V}$ obou dvou symetricky uspořádaných zástupech, kde jsou postavy v popředí klečící a v pozadí stojící, jsou kromě ke středu upřeným zrakům všech zúčastněných společným prvkem růžence s červenými kuličkami, jež drží v rukou sepnutých v modlitbě.

3 Adolf Nowak, Církevní památky umělecké z Olomouce I, Olomouc 1890, s. 24-25. Zcela první zmínka o nástěnné malbě se objevuje již roku 1883, kdy bylo zhodnoceno její nedávno proběhnuté odkrytí a s tím spojené restaurování, viz August Prokop, Aus Olmütz, Mittheilungen k. $k$. Central-commission zur Erforschung und Erhaltung der Kunst-und historischen Denkmale, Neue Folge IX, 1883, s. 105-109, cit. s. 108.

4 František Bolek, Katolické kostely a kaple v Olomouci, Olomouc 1936, s. 52. V textu není vůbec zmíněno poslední restaurování roku 1932 pod vedením Jana Janši, při němž stejně jako při prvním na počátku osmdesátých let 19. století nebyly dodrženy stanovené zásady a malba byla v některých partiích výrazně pozměněna.

5 Ivo Hlobil, K ikonografii, symbolice a významu růžencového obrazu v kostele Neposkvrněného početí Panny Marie v Olomouci-Bělidlech, Sborník památkové péče v Severomoravském kraji I, 1971, 9-16.

6 Antonín Kalous, Declaratio brevis Corone immaculate virginis: A source for Late Medieval Popular Piety, Umění LV, 2007, s. 40-44.

7 Spodní ohraničení této partie, tedy vlastně celého obrazu zcela chybí z důvodu poškození pekováním. K výraznějším ztrátám svrchních barevných vrstev došlo téměř po celém obvodu malby. 
Spojujícím prvkem mezi dolní a střední partií výjevu partií je růženec v podobě pásu kuliček na tmavém pozadí. [Obr. 3] Celkový počet kuliček je sedmdesát jedna a vždy po deseti červených je vložena jedna žlutá kulička většího průměru. Střední partie je dále rozdělena na dvě horizontální pásma, jež obsahují shodně po sedmi vyobrazeních, znázorňujících sedm radostí Panny Marie (Zvěstování Panně Marii, Navštívení Panny Marie, Narození Krista, Klanění mudrcủ, Očištování Panny Marie, Nalezení Krista v chrámu a Korunování Panny Marie) a sedmi bolestí Bohorodičky (Obřezání Krista, Kristus na hoře Olivetské, Bičování Krista, Korunování trním, Svlékání Krista z roucha, Přibijení Krista na křiž, Ukřižování). Pásma jsou zasazena do iluzivních, téměř čtvercových polí, která jsou od sebe oddělena jednoduchými iluzivními sloupky s odstupňovanými hlavicemi a patkami vynášejícími iluzivní kladí. Zcela ve vrcholu, v nejvyšší části růžencového obrazu jsou proti sobě v letu zobrazeni dva andělé nesoucí velkou korunu, která se liší od ostatních zobrazených na malbě. [Obr. 4] Rozměrná trojitá liliová koruna je zdobena vzácnými kameny a ve vrcholu zakončena kytkou, usazenou na dvou vnitřních, překřížených a vzhůru klenutých kamarách. V pozadí za korunou je v iluzivně provedeném výklenku znázorněna tmavě modrá obloha. Pod výklenkem, jenž je zakončen stlačeným obloukem, je umístěna datace malby 1500.

\section{Ikonografie - spodní partie}

Ústřední postavou nejen ve spodním pásu je korunovaná Panna Marie ve sluneční záři s Ježíškem v náručí. Motiv Assumpty je charakteristický pro prostředí františkánů-observantů, a současně je i dobovým symbolem katolicismu. Obraz ženy na půlměsíci vychází z prvního verše dvanácté kapitoly knihy Zjevení sv. Jana, v němž stojí: „A ukázalo se veliké znamení na nebi: Žena oděná sluncem, s mésícem pod nohama a s korunou dvanácti hvězd kolem hlavy“ (Zj 12,1$)$. V případě nástěnné malby v kostele Neposkvrněného početí v Olomouci však došlo k prolnutí obrazu Madony a apokalyptické ženy, ${ }^{8}$ s čímž je spojena i obměna hvězd na koruně za lilie. Jedná se tudíž o zobrazení Assumpty, u níž je možné s ohledem na spojení symbolického významu lilie, jakožto atributu nevinnosti a tělesné i duchovní čistoty, a koruny, jež již od raně křestanského umění odkazovala k neposkvrněnému početí, uvažovat o vyjádření postavení františkánů v otázce neposkvrněného početí Panny Marie, která byla po dlouhou dobu hlavním tématem jejich polemiky vedené s dominikány. ${ }^{9}$ Tuto úvahu podporuje text i jeho sa-

8 Nejstarší vyobrazení v českém umění, na němž se setkáváme s tímto spojením, se nachází ve Velislavově bibli. Někteří teologové, jako např́klad Richard de St. Laurent, viděli už v samotné apokalyptické ženě zobrazení Nanebevzaté Panny Marie, viz Jutta Fonrobert, heslo Apokalyptisches Weib, in: Engelbert Kirschbaum (ed.), Lexikon für christlichen Ikonographie I, Freiburg im Breisgau 1994, s. 146.

9 Významnou roli v této době rovněž sehrál papež Sixtus IV., jenž byl příslušníkem řádu menších bratří, viz Rona Goffen, Friar Sixtus IV. and the Sistine Chapel, Renaissance Quarterly XXXIX, 1986, s. 218-262. Stejně jako všichni františkáni byl i on velkým přínnivcem Panny Marie, jíž projevoval úctu mnoha způsoby. Mezi nimi lze jmenovat zavedení svátku Uvedení Panny Marie do chrámu roku 1472, schválení statut prvního oficiálního růžencového bratrstva v Kolíně nad Rýnem roku 1475 či zavedení svátku Navštívení Panny Marie téhož roku. Ve stejném roce dokonce svolal debatu ohledně Mariina neposkvrněného početí, $\mathrm{k}$ níž byli pozváni jak františkáni, tak jejich ideoví protivníci, dominikáni. 
motný název, publikovaný Antonínem Kalousem roku 2007, ${ }^{10}$ v němž se o Panně Marii hovoří jako o Immaculatě. Přestože k pevnému ustanovení typu Immaculaty došlo až v polovině 17. století, počátky její ikonografie je možné spojit se snahami papeže Sixta IV., 11 jež byly završeny vydáním jeho dvou bul, a to Cum prae excelsa roku 1476 a Grave nimis o sedm let později.

$\mathrm{Na}$ základě výše uvedeného lze předpokládat, že se v olomouckém případě jedná v první řadě o zobrazení Assumpty, ${ }^{12}$ jejíž koruna odkazuje na její nanebevzetí a určuje ji jako královnu nebes. ${ }^{13} \mathrm{~S}$ touto interpretací konvenuje i oddělení Assumpty od věřících po jejích stranách pomocí nízké zídky a odlišného, abstraktního zlatého pozadí, vymezeného architekturou po stranách, před níž jsou shromážděni zástupy věřících. Sama barva pozadí za Pannou Marií je s ohledem na symboliku barev důležitá a má nepochybně svůj význam. Zlatá barva je obvykle spojována s božstvím a vyjadřuje Boží svět, ${ }^{14}$ čímž dochází ke zdůraznění odlišného postavení Panny Marie s Ježíškem v náručí a věřících, znázorněných po jejích stranách, avšak v odlišné významové rovině.

Jak upozornil Ivo Hlobil, ${ }^{15}$ lze korunu Assumpty spolu se dvěma dalšími, nesenými anděly po obou stranách její hlavy, považovat za části trojdílné koruny, jež podle vidění sv. Františky Římské značí Mariinu neposkvrněnost, pokoru a oslavení. ${ }^{16}$ Celá koruna, složená ze všech částí, je pak zobrazena zcela ve vrcholu výjevu, kde je rovněž nesena dvěma anděly. Tím se vracíme k názoru, vyslovenému Adolfem Nowakem na konci 19. století, ${ }^{17}$ který pozdější literatura nereflektuje a který označuje korunu jako císařskou, a nikoliv jako mariánskou. Tomu by však neodpovídala ani celková symbolika obrazu, jež je vyložena v textu objeveném Antonínem Kalousem, ani postoj františkánů, kteří byli zastánci nadřazenosti papežství nad císařstvím. K této domněnce nás vede nejen zmíněný text, jemuž obraz plně odpovídá, vyjma počtu kuliček spojujících spodní a střední pás. Kromě toho, pokud je podle Iva Hlobila spojujícím prvkem mezi spodním a středním

10 Kalous (pozn. 6), s. 43-44.

11 Již v roce 1472 vedl papež Sixtus IV. dne 8. prosince kázání o Neposkvrněném početí Panny Marie, které na daný den připadá, viz Maurice Dejonghe, Roma santuario Mariano, Bologna 1970, s. 120. Šírení jeho myšlenek i mimo území Itálie dokládá na našem území postava františkána Jana Bosáka Vodňanského a jeho spis z roku 1509, Traktát o početí prečistém a neposkvrněném dưstojné Panny Marie.

12 Roku 1475 vydal výše vzpomínaný papež Sixtus IV. odpustkovou listinu se zobrazením Assumpty, tedy Panny Marie s Ježíškem v náručí, jež byla sluncem oděná a stojící na půlměsíci. Jelikož se toto zobrazení následně ustálilo, jak dokládá obraz Rủžencové Madony z Kolína nad Rýnem či vratislavský deskový obraz, a to s největši pravděpodobností bez ohledu na řádovou př́slušnost, lze vyobrazení z odpustkové listiny považovat za prototyp pro znázornění Panny Marie Růžencové. Mirella Levi D'Ancona, The Iconography of the Immaculate Conception in the Middle Ages and Early Renaissance, New York 1957, s. 26.

13 Jules Lutz - Paul Pedrizet (edd.), Speculum humanae salvationis, Leipzig 1907, s. 99. Tomuto určení odpovídají i přímluvná gesta klečících osob, shromážděných kolem Madony, nebot nanebevzatá Panna Marie byla dlouhou dobu vnímána jako prostřednice, coredemptorix, přimlouvající se za lidi, viz Josef Cibulka, Korunovaný Assumpta na pưlměsíci. Př́íspěvek k české ikonografii XIV.-XVI. století, in: Jan Štenc (ed.), Sborník k sedmdesátým narozeninám K. B. Mádla, Praha 1929, s. 80-127, cit. s. 95.

14 Stejnou ideu nalezneme i v textu žalmu In sole posuit tabernaculum suum (Ž 18,6$)$, který použil při svém kázání v Sieně v první polovině roku 1425 i Bernardin Sienský, viz Le prediche volgari inedite, Firenze 1424-1425, Siena 1425 (ed. Dionisio Pacetti), Siena 1935, s. 539-540.

15 Hlobil (pozn. 5), s. 10.

16 Philipp Schmidt, Edelsteine, in: Konrad Algermissen - Ludwig Böer - Carl Feckes et al., Lexikon der Marienkunde, Regensburg 1967, col. 1499-1503, cit. col. 1501.

17 Nowak (pozn. 3), s. 25. 
pásmem růžencová šňůra, je nutné k předchozím dvěma partiím připojit i nejvyšší pásmo, což vylučuje zobrazení císařské koruny, jež nemá s předchozími partiemi žádnou spojitost. Tímto spojením je celý obraz v čele klenby jižní boční lodi jednotným vyobrazením Koruny Panny Marie. V př́ípadě správnosti této interpretace není nutné přikládat významy jednotlivým pásům na obraze, jak učinil Ivo Hlobil, ${ }^{18}$ a proti čemuž vznesl námitky Pavol Černý, ${ }^{19}$ aniž by však nabídl novou interpretaci výjevu jako celku.

Obdobné podání lze nalézt i na obraze s názvem Corona beatisiimae Virginis Marie Z vratislavského kláštera bernardinů, ${ }^{20}$ na nějž upozornil již Antonín Kalous. ${ }^{21}$ [Obr. 5] Ve spodní partii deskového obrazu je zobrazena Assumpta v podobě Madony ve slunci oděné a stojící na půlměsíci v obklopení observantů, nad nimiž se vznáší dva andělé nesoucí ohromnou korunu nad hlavou Panny Marie. ${ }^{22}$ Ta však na rozdíl od olomoucké nástěnné malby obsahuje kromě zobrazení sedmi radostí a sedmi bolestí Panny Marie medailony s vyobrazením sedmi zástupců nebeských hierarchií, ${ }^{23} \mathrm{~s}$ personifikací sedmi smrtelných hř́íchů, ${ }^{24}$ sedmi ctností, ${ }^{25}$ sedmi darů Ducha svatého a sedmi představitelů pozemského života. ${ }^{26}$ Naopak na vratislavské desce postrádáme zobrazení koruny v její horní partii, což je snad právě možné vysvětlit přítomností dalších pěti pásů po sedmi medailonech, které v Olomouci zastoupeny nejsou a byly tudíž nahrazeny vrcholovou korunou, za níž je v kamenném ostění iluzivně proražený výklenek. Slovo corona se rovněž objevuje i v názvech mariánských modliteb, jak např́klad dokládá ta od sv. Bonaventury s titulem Corona Beatae Mariae Virginis, ${ }^{27}$ či byla pro kartuziány, jež měli značný podíl

18 Hlobil (pozn. 5), s. 13.

19 Pavol Černý, Růžencová madona, in: Ivo Hlobil - Marek Perůtka (edd.), Od gotiky k renesanci: výtvarná kultura Moravy a Slezska 1400-1550. III., Olomoucko (kat. výst.), Olomouc 1999, s. 410-413.

20 Katarzyna Zalewska, Modlitwa i obraz. Średniowieczna ikonografie róźancowa, Warszawa 1999, s. $75-104$.

21 Kalous (pozn. 6), s. 42.

22 Čelenka koruny na vratislavském obraze je stejně jako v Olomouci zdobena kuličkami růžence.

23 Jsou zde vyobrazeni andělé, apoštolové, sv. mučedníci, sv. biskupové, sv. vdovy, sv. panny a všichni svatí.

24 Medailony s jejich vyobrazením jsou řazeny v následujícím sledu, a to pýcha, závist, hněv, lenost, smilstvo, obžerství a lakomství.

25 Ctnosti, kde je personifikace pokory, lásky k bližnímu, mírumilovnost, zbožnost, cudnost, pokora a stř́ídmost, jsou postaveny do protikladu k sedmi smrtelným hř́íchům.

26 Mezi sedmi dary Ducha svatého je zastoupena bázeň před Hospodinem, rozumnost, poznání, síla, rada, zbožnost a moudrost. Nejvýše umístěné medailony jsou vyplněny postavami lidí, za které je nutné se modlit či kteří se sami svěřili do péče Panny Marie, a to v následujícím pořadí: rodiče s dětmi, duchovní, světští vládci, dva mniši, lidé v nouzi, hř́šníci a duše zemřelých v očistci.

27 Mezi dalšími př́íklady lze jmenovat modlitbu s názvem Maagdenkron, připisovanou sv. Brigitě, viz Frances van den Oudendijk Pieterse, Dürers „Rosenkranzfest“ en de ikonografie der Duitse rozenkransgroepen van de XVe en het begin der XVIe eeuw, Amsterdam 1934, s. 573. Ve Vědecké knihovně v Olomouci se nachází rukopis Corona beatae Mariae Virginis z doby před rokem 1505, sign. II 48.486-II 48.487. Tento spis, jenž se vrací k prvnímu verši dvanácté kapitoly Zjevení sv. Jana, přisuzuje Panně Marii, jakožto matce Krista a Bohem vyvolené panně, až dvanáct korun, značících její ctnosti, nebot jedna koruna je vyhrazena pouze smrtelníkům. Touto interpretací tak navazuje na pojednání od františkána Oswalda Pelbartuse z konce 15. století Stellarium Coronae Beatae Mariae Virginis, v němž hvězdy na koruně Panny Marie odkazují na její nevinnost a dary, jimiž byla jako Bohorodička obdařena. Jeden exemplář tohoto spisu z roku 1498 je v současné době rovněž uchováván ve Vědecké knihovně v Olomouci, sign. II 48.275. 
na vývoji růžencové zbožnosti především díky Adolfu z Essenu a jeho žákovi Dominikovi $\mathrm{z}$ Prus, synonymem pro samotnou růžencovou modlitbu. ${ }^{28}$

Představitelé duchovní a světské moci, rozmístění symetricky po stranách Assumpty, byli v minulosti často ztotožňováni se skutečnými historickými osobnostmi. Z výše uvedených badatelů, již se problematice nástěnné malby v kostele Neposkvrněného početí Panny Marie věnovali, rozpracoval nejvíce tuto teorii Pavol Černý, a to především na základě úvah o sakrálních identifikačních portrétech na růžencovém obraze z Kolína nad Rýnem, jež vnímá jako blízkou analogii. Papeže identifikuje se vzpomínaným pontifikem Sixtem IV., mezi řeholníky poznává samotného zakladatele kolínského růžencového bratrstva Jacopa Sprengera. Dvě přední postavy na opačné straně ztotožňuje s císařem Friedrichem III. a jeho synem Maxmiliánem. Mezi duchovními ještě rozpoznává kardinála Alexandra, jenž měl rovněž podíl na schválení kolínského růžencového bratrstva, či Heinricha Institorise $\mathrm{v}$ řádovém dominikánském šatu $\mathrm{s}$ tonzurou na hlavě. V muži s výraznými gesty spatřuje kazatele Jana Kapistrána a samozřejmě nevynechává ani tehdejšího olomouckého biskupa Stanislava Thurzu. Na protější straně, kam hypoteticky vkládá i postavu donátora, vidí v podobizně vysoce postaveného muže v šatě s hermelínovým límcem Viléma z Perštejna. Otázkou přesto stále zůstává, zdali je nutné zobrazené postavy interpretovat jako sakrální identifikační portréty, zvláště nemá-li většina identifikovaných postav osobní vztah k olomouckému kostelu.

K pozastavení nad úvahou Pavola Černého mě vede několik bodů. Prvním z nich je skutečnost, že portrétované osoby na vzpomínaném kolínském obraze, k němuž Pavol Černý odkazuje, byly př́mo spjaty s růžencovým bratrstvem či byly dokonce jeho členy, což v př́padě olomouckého obrazu neplatí, nebo tuto skutečnost nelze z důvodu nedochování knih bratrstva ověřit. Druhým důvodem je předpokládané zobrazení osobností, které nežily ve stejné době. Mezi duchovními se jedná o papeže Sixta IV., který umřel roku 1484, a Alexandra, biskupa z Forli, jenž zemřel následujícího roku, a vedle nichž by měl být zobrazen Stanislav Thurza, zvolený za olomouckého biskupa až roku 1496. Mnohem větší časový rozdíl je ještě mezi Janem Kapistránem, jenž zemřel roku 1456, a Heinrichem Institorisem, který působil v Olomouci až po ustanovení Stanislava Thurzy biskupem. ${ }^{29}$ Mezi světskými zástupci vyvolává pochybnosti zobrazení Viléma II. z Perštejna, jehož manželka Johanka z Libic byla ochránkyní českých bratrů, vůči nimž bojoval přímo na Moravě kolem roku 1500 Heinrich Institoris.

Pavol Černý přitom ve svém př́spěvku vůbec nereflektuje osobnost Jana Filipce, přestože se před uvedením Stanislava Thurzy do funkce biskupa jednalo o dlouholetého, avšak papežem neuznaného administrátora olomoucké diecéze a významného diplomata ve službách Matyáše Korvína, který byl současníkem Viléma II. z Perštejna a ke konci

28 Dominik z Prus je současně autorem traktátu ze třicátých let 15. století s názvem Corona gemmatia Beatae Mariae Virginis, jenž byl kolem roku 1450 přeložen i do němčiny, viz Karl Joseph Klinkhammer, Adolf von Essen und seine Werke, Frankfurt am Main 1972, s. 80.

29 Zde patrně Pavol Černý vychází z myšlenky universa fraternitas, zdůrazňující sounáležitost živých a mrtvých. S touto úvahou souvisí i změna při znázornění postav na náhrobcích, jak na ni poukazuje Philippe Ariès, Dějiny smrti I., Praha 2000, s. 311-312. Ten na základě četných př́íladů upozorňuje, že modlící, bez ohledu na to, zdali je živý či mrtvý, je osoba, jež se dostala do nadpozemského světa a jejiž gesta předjímají její spásu. Prezentovaným setřením hranice mezi pozemským a nebeským světem by se dala rovněž př́padně vysvětlit přítomnost skutečných historických postav $\mathrm{z}$ různých časových období na jednom obraze vedle sebe. 
života sám řádovým členem bernardinského kláštera ve Vratislavi. Na základě uvedených skutečností vyvstává možnost, zdali se v př́padě obrazu v olomouckém kostele nejedná pouze o reprezentativní výběr zástupců $z$ duchovních a světských řad, jejichž přítomnost měla věřícím, jež se před obrazem modlili růženec, připomínat, že všichni členové růžencového bratrstva si jsou rovni bez ohledu na své sociální postavení, protože hlavním a jediným účelem růžencového bratrstva bylo sdílení modliteb s bratry a sestrami. Důraz na nedůležitost postavení ve společnosti a s ním spojeného vlastnictví osobních statků hrál u františkánů-observantů roli, jak dokládá i jejich odmítání řádového vlastnictví majetku. Při interpretaci věřících po stranách Assumpty je rovněž důležitá myšlenka universa fraternitas, zdůrazňující sounáležitost živých a mrtvých. ${ }^{30}$ Pro ně je žádán klid a odpočinek při očekávání konce věků a pro živé spása.

Uvedenou hypotézu potvrzuje i zobrazení řádových bratři při levém okraji. Ti byli na základě barev svých hábitů určeni Františkem Bolkem jako bernardin, minorita, kartuzián a dominikán. ${ }^{31}$ Odlišného názoru byl Pavol Černý, jenž na obraze shledal pouze přítomnost dominikána v pozadí, ztotožněného s Heinrichem Institorisem, dvou minoritů a bernardina, jenž je dle něj zpodobněním Jana Kapistrána, zachyceného ve výrazném gestu. Následující řádky lze s ohledem na částečně setřené barevné vrstvy přijmout jen s opatrností, avšak i přesto se domnívám, že jsou zde, jak uvádí Pavol Černý, vyobrazeni zástupci tří mnišských řádů. V případě klečícího mnicha s rukama zkříženýma na hrudi se dle jeho světlého hábitu, snad původně bílé barvy, který býval přepásán koženým řemenem, na němž byl při levém boku zavěšen patnáctidesátkový růženec a jenž byl doplněn límcem s kapucí téže barvy, ${ }^{32}$ jedná o dominikána. Za ním jsou rovněž v pokleku zobrazeni dva františkáni v tmavohnědých hábitech s kapucí, jež byly přepásány provazovým cingulem. ${ }^{33}$ Zcela v pozadí je pak vestoje zachycen minorita, jehož řádový oblek měl od sedmého generálního ministra, sv. Bonaventury, ${ }^{34}$ černou barvu. Zdali byla tunika přepásána bílým provazovým cingulem se třemi uzly, nelze pro zobrazení pouze jeho horní poloviny těla určit, avšak růženec, který obsahoval sedm desátků a který drží v sepnutých rukách před sebou, je blíže levému boku, u něhož býval zavěšen. Všechny uvedené žebravé řády měly v Olomouci své zastoupení, nebot dominikáni se vyskytovali v konventu u kostela sv. Michala, minorité do roku 1576 v klášteře u sv. Františka s kostelem Panny Marie a františkáni-observanté pochopitelně v konventu u zde zkoumaného kostela Neposkvrněného početí Panny Marie a Bernardina Sienského. Jak již naznačil Ivo Hlobil, je možné vnímat zobrazení dominikána na obraze spolu s františkány, minority a dalšími duchovními postavami jako společný boj církve proti českým bratřím, čímž se malba stává součástí ideologického boje zasazeného do moravské metropole na přelomu 15. a 16. století. Pro všechny předpokládané mendikantské řády zastoupené na obraze

$30 \mathrm{~S}$ touto úvahou souvisí i změna při znázornění postav na náhrobcích, jak na ni poukazuje Philippe Ariès, viz Philippe Ariès, Dějiny smrti I., Praha 2000, s. 311-312. Ten na základě četných př́kladů upozorňuje, že modlící, bez ohledu na to, zdali je živý, či mrtvý, je osoba, jež se dostala do nadpozemského života a jejíz gesta předjímají spásu. Prezentovaným setřením hranice mezi pozemským a nebeským světem by se dala rovněž prípadně vysvětlit přítomnost skutečných historických postav z různých časových období na jednom obraze vedle sebe, jak soudí Pavol Černý.

31 Bolek (pozn. 4), s. 52.

32 Milan Buben, Encyklopedie řádů, kongregací a řeholních společností katolické církve v českých zemích III/1, Praha 2006, s. 114.

33 Ibidem, s. 229.

34 Ibidem, s. 132. 
byla ovšem kromě jejich působení v Olomouci a sdílení stejné myšlenky společná ještě postava Panny Marie, již všechny tyto řády uznávaly nejen jako svojí patronku, ale rovněž se výrazně podílely na šíření růžencové zbožnosti, která je hlavní náplní tohoto obrazu.

Růženec $\mathrm{v}$ podobě kuliček navlečených na šňůru po celé šířce obrazu navazuje jak na růžence, které věřící, včetně Ježíška, drží v rukou, tak na sedm vyobrazení ve střední partii obrazu. Růženec začíná žlutou kuličkou většího průměru, která představuje jeden Pater Noster, a za ní následuje deset menších červených kuliček. Tím vzniká sedm částí, k nimž se váže stejný počet zobrazení připomínající radosti a bolesti Panny Marie. Samotný počet kuliček není náhodný, nýbrž číslo sedmdesát jedna vyjadřuje počet let, strávených Pannou Marií na zemi. ${ }^{35}$ Počet kuliček růžence je jediné místo, kde se nástěnná malba odlišuje od textu publikovaného Antonínem Kalousem, nebot v něm je uvedeno, že Panna Marie prožila na zemi šedesát tři let. Tato číslovka se pak plně přidržuje podání Bernardina Sienského, ${ }^{36}$ jenž se měl již jako malý chlapec modlit růženec se šedesáti třemi Ave Maria před obrazem Nanebevzetí Panny Marie.

\section{Ikonografie - prostřední partie}

Čtrnáct výjevů, připomínajících důležité okamžiky ze života Panny Marie a Krista, tvoří styčné body nejen při samotné kontemplaci, ale současně pro spásu lidské duše, nebot’ milosti lze dosáhnout pouze prostřednictvím modliteb. Ty, jak bylo řečeno výše, byly nejdůležitější a v podstatě jedinou podmínkou účasti v růžencových bratrstvech. Řádoví bratři modlící se růženec si tak připomínali zásadní momenty ze života Krista a jeho matky Panny Marie, prostřednictvím nichž dospěli až ke kontemplaci. Laičtí členové fraternit pak vnímali modlitbu růžence, při níž jim jako mnemotechnická pomůcka posloužila vyobrazení klauzulí vážící se k výtvarné podobě Ave Marie a Pater Noster, především jako způsob př́mluvy a ochrany před nástrahami pozemského života. Ve dvou řadách nad sebou je vyobrazeno sedm výjevů, jejichž počet je záměrný, nebot číslo sedm považovali již církevní otcové za dokonalé, ${ }^{37}$ jak dokládá mimo jiné i počet darů Ducha svatého.

Sedm je rovněž drahých kamenů na koruně Panny Marie, jež symbolizují jak její vlastnosti, tak její úlohu v dějinách spásy. ${ }^{38}$ Jedná se o asterit, achát, chalcedon, sardonyx, chryzopras, chrizalit a allectorius. Asterit (latinsky asterites) je dle Johannese ze St. Geminiana přirovnáván $\mathrm{k}$ panenství, ${ }^{39}$ protože se díky bílému povrchu podobá neposkvrněnému tělu, obsahujícímu uvnitř hvězdu zářící jako světlo božské milosti. Soustředěné bílé proužky na černém základu achátu naznačují, že i přes temnotu a hřích je věřící skrze neustálou modlitbu schopen dosáhnout očištění a dojít i spasení. Přestože chalcedonu

35 V době kolem roku 1500 se lze také často setkat s počtem 63, 70 nebo 72, jež patří spolu s výše uvedeným počtem kuliček mezi nejčastější.

36 Stephan Beissel, Geschichte der Verehrung Marias im 16. und 17. Jahrhundert, Freiburg im Breisgau 1910, s. 39.

37 Heinz Meyer, Die Zahlenallegorese im Mittelater, München 1975, s. 133-138. - Ursula Grossmann, Studien zur Zahlensymbolik des Mittelaters, Zeitschrift für katolische Theologie LXXVI, 1954, s. 19-54.

38 Bernardino Busti, Mariale. De singulis festivitatibus beatae Virginis per Modum sermonum tractans, Argentinae 1496 (Vědecká knihovna v Olomouci, sign. II 48.274), f. 25-26.

39 Johannes de Sancto Geminiano, Summa de exemplis et rerum similitudinibus locupletissima verbi Dei concionatori (ed. Egidio Gravatio), Antverpiae 1597, fol. 18v, http://www.e-rara.ch/zuz/content /pageview/11558818, vyhledáno 19.6.2016. 
není přisuzováno mnoho symbolických významů, ve výkladu Johannese ze St. Geminiana je připodobňován $\mathrm{k}$ Panně Marii, ${ }^{40}$ jež je nejen př́mluvkyní u posledního soudu, ale rovněž ochránkyní věřících před nástrahami pozemského života. Obdobně v podání téhož autora vyznívá sardonyx, nebot’ stejně jako má tento minerál barev, má Panna Marie ctností. Mezi nimi vyzdvihuje především pokoru, duševní i tělesnou neposkvrněnost a lásku, bez níž by ostatní ctnosti neměly takového významu. Chryzopras i chrysolit, jež jsou ve Zjevení sv. Jana (Zj 21, 20) jmenovány jako dva z dvanácti základních kamenů nebeského Jeruzaléma, tvoří dle Pseudo-Hildefonda i součást Mariiny koruny, ${ }^{41}$ jejíchž jednotlivých dvanáct kamenů odkazuje na její ctnosti. V př́ípadě chalcedonu se jedná o moudrost Panny Marie a její panenství, u chrysolitu o její zbožnost a lásku, jíž zahrnovala všechny, a současně její nelehký osud jako matky Ježíše Krista. Poslední kámen allectorius, o jehož symbolickém významu pojednává sám autor spisu Busti, ${ }^{42}$ je opět přirovnáván přímo $\mathrm{k}$ Panně Marii, a to ve smyslu fons paradisi, protože ona stejně jako její syn dokáže utišit touhu po věčné spáse.

Při interpretaci zobrazení těsně nad růžencem se na rozdíl od Pavola Černého, jenž je v návaznosti na výkladu Františka Bolka vnímá jako antinomii sedmi radostí a sedmi bolestí Panny Marie, ${ }^{43}$ zaměřených na olomouckém obraze úžeji na sedm prolití Kristovy krve, přikláníme k návaznosti jednotlivých výjevů na sebe, v nichž ústřední postavou je Panna Marie. Nebot se jedná o Bohorodičku, vyvolenou Bohem a zbavenou všech hříchů, jež provázela Krista po celý jeho pozemský život a sdílela s ním všechna jeho utrpení a ponížení, z nichž některá, jak dokládá Kristovo obřezání, jsou spojitelná již s Ježíšovým dětstvím, až do jeho smrti na kř́iži. Po jejím nanebevzetí, jež je posledním zobrazením, pak byla korunována Kristem a Bohem a usedla vedle nich jako královna nebes.

Ideu spoluutrpení Panny Marie, která je zachycena na třech výjevech včetně Ukřižování, kde její compassio vedlo až k mdlobám, rozpracovali ve 12. století cisterciáci, a to především zásluhou Bernarda z Clairvaux a jeho spisu De planctu beatae Mariae. ${ }^{44}$ Výraznými pokračovateli pak byli především servité a rovněž františkáni. Na zajímavou spojitost mezi sedmi prolitími Kristovy krve a sedmi smrtelnými hříchy poukázal ve svém kázání In festo circumcisionis domini, jež bylo vydáno jako součást Semones Pomerii Quadragesimales ${ }^{45}$ na samém závěru 15. století františkán Oswald Pelbartus. Nebot’ při obřezání byla překonána lakota, při pobytu na hoře Olivetské obžerství, při bičování závist, při korunování trním pýcha, při svlékání z roucha chtíč, při přibíjení na kř́iž lenost a př̀i ukřižování hněv. Dle něho by si měl věřící při každé scéně zachycující prolití Kristovy krve uvědomit, že se Ježíš obětoval pro spásu lidstva, a vystř́ihat se všech nástrah zla. Tomu odpovídá i druhá část zpěvu Dies irae, vzniklá ve 13. století ve františkánském prostředí, kde je připomínáno Kristovo pozemské působení, zakončené jeho smrtí, pro vykoupení lidského pokolení. Dle Ericha Wimmera souvisí ustálení počtu prolití Kristovy krve na

\footnotetext{
Ibidem, fol. $9 \mathrm{v}$.

Pseudo-Ildephonsus de Toledo, Libellus de corona Virginis (ed. Jacques Paul Migne), Paris 1854, s. 96.

Busti (pozn. 38), f. 45.

Černý (pozn. 19), s. 412.

Eugène Druve, La méditation universelle de Marie, Maneir, 1949, s. 420-568, cit. s. 500.

45 Jeden exemplář rukopisu je v současné době uložen i ve Vědecké knihovně v Olomouci, sign. II.660.402. Přestože se jedná o tisk z roku 1509, je možné, že olomoučtí bernardini mohli znát Pelbartusovo kázání, stejně jako byli obeznámeni s jeho traktátem Stellarium Coronae Beatae Mariae Virginis, jenž byl připomenut výše.
} 
sedmi se stejným počtem denních modliteb a současně jako analogie k sedmi radostem Panny Marie, ${ }^{46}$ jejichž kult byl propagován především františkány. ${ }^{47}$ Značný podíl na jeho šíření měl rovněž sv. Bernardin Sienský, ${ }^{48}$ jak dokládá i nošení korunky, symbolizující sedm radostí Panny Marie, zavěšené na cingulu, stejně jako jeho žák a pokračovatel Jan Kapistrán, ${ }^{49}$ který připojením sedmi radostí Panny Marie a následně jejích sedmi bolestí $\mathrm{k}$ modlitbě růžence rozšíril růženec sv. Brigity Švédské.

Cyklus sedmi radostí Panny Marie vznikl v okruhu servitů, ${ }^{50}$ ale brzy byl přijímán i dalšími mnišskými řády, jak dokládají i tato zobrazení ve františkánském kostele, pouze s výjimkou posledního výjevu, ${ }^{51}$ jenž je zde nahrazen Nanebevzetím Panny Marie.

Všechny výše uvedené scény spojuje pochopitelně postava Panny Marie, které je ve františkánském prostředí přisouzena role zprostředkovatelky mezi církví a Kristem, tak jako byl Kristus prostředníkem mezi Bohem a člověkem. První výjev znázorňující Zvěstování Panně Marii představuje věřícím počátek tohoto vztahu, kde je Panna Marie prezentována v souladu s názorem františkánů-observantů jako neposkvrněná a čistá panna, Bohem vyvolená budoucí matka Krista počatého rovněž bez prvotního hříchu. U dalšího obrazu Navštívení Panny Marie je v souvislosti s cyklem, do nějž je scéna vkomponována, nutné především zdơraznit čtyřicátý druhý verš první kapitoly Lukášova evangelia, kde je Panna Marie vyzdvihována nad všechny ženy a kde je akcentována její role jakožto Kristovy matky. Kristovy jesličky, jež mají ve třetím výjevu Adorace Páně spíše podobu tumby, odkazují na jeho budoucí osud, čímž je současně připsána významná role Panně Marii, nebot’ stála jak na počátku Ježíšova pozemského života, tak na jeho konci, jež je spojitelný s tumbou, do níž byl Pannou Marií po smrti na kř́řži pohřben.

V komorně pojednaném výjevu Klanění mudrců, v němž je Kristu a současně i jeho matce Panně Marii, jež ho drží ve svém klíně, vzdávána úcta a obdiv, se stejně jako v předchozích zobrazeních setkáváme v rámci dějin spásy s důrazem kladeným nejen na Krista, ale rovněž i na Pannu Marii. Stejně jako lze tři dary mágů považovat za symboly spojitelné s Ježíšem, ${ }^{52}$ mohou mít současně význam i ve vztahu k Bohorodičce, nebot zlato může představovat její oddanost, kadidlo její zbožnost a myrha neposkvrněnost a nezkažené tělo, o němž byli františkáni jednoznačně přesvědčeni. V souvislosti s tímto názorem od-

46 Erich Wimmer, Maria im Leid, Die Mater Dolorosa in der deutschen Literatur und Frömmigkeit des Mittelalters (Dissertation), Philosophische Fakultät Julius-Maximilians-Universität, Würzburg 1968, s. 92.

47 Bernardino Barban, La corona dei sette gaudi, La Madonna nella spiritualita francescana V, 1963, c. $126-132$, cit. s. $128-129$.

48 Ibidem, s. 130.

49 Beissel (pozn. 36), s. 38.

50 Zásluhou stejného řádu se v téže době, tedy na přelomu 12. a 13. století, začala šírit i úcta $\mathrm{k}$ Panně Marii Bolestné, jež byla doprovázena obdobným cyklem sedmi zobrazení jako v případě radostných okamžiků ze života Bohorodičky. První písemná zmínka o obou cyklech, stejně jako svátku Panny Marie Bolestné, je doložena z roku 1423, kdy se konala diecézní synoda v Kolíně nad Rýnem. Viz Ivana Vavrušová, Mariánská tematika v duchovní hudbě českého baroka (diplomová práce), CMTF UP, Olomouc 2009, s. 10.

51 Sedm radostí Panny Marie je i v př́ípadě Jana Kapistrána zakončeno Korunováním Panny Marie, a nikoliv jejím Nanebevzetím, jak je tomu v Olomouci. Tuto odlišnost je možné vysvětlit odkazem na papeže Sixta IV. a jeho velkou úctu k Panně Marii.

52 Darovaným předmětům připsal Beda Ctihodný následující symboly. Zlato značí Kristovu královskou důstojnost, kadidlo jeho božství a myrha naznačuje jeho budoucí utrpení a smrt. Nebot' když na kříži požádal pro žízeň o vodu, dostalo se mu směsi octa, žluče a myrhy pro urychlení jeho smrti. Podobný výklad podává i Zlatá legenda, viz Jacobus de Voragine, Legenda Aurea, Praha 1984, s. 124. 
kazuje i výjev Očištování Panny Marie na její ctnost, pokoru a zbožnost - na Pannu Marii se tento zákonný zvyk nevztahoval, nebot’ sama byla již v lůně sv. Anny naprosto čistá a posvěcená a sama následně počala Krista z Ducha svatého, a nebyla tudíž po narození svého Božího Syna nečistá jako všechny ostatní ženy po porodu svých potomků. První tři verše sto desátého žalmu lze vztáhnout k obrazu Nanebevzetí Panny Marie, nebot’ je v nich spatřováno překonání smrti Pannou Marií, a tím současně i její př́ičiny, tedy prvotního hříchu. Tato představa došla značného rozšíření ve 13. a 14. století především mezi františkány, ${ }^{53}$ kteří ji spojovali s kultem Neposkvrněného početí Panny Marie. Velké obrody se jí pak dostalo ještě na konci 15. století, v jehož samém závěru vznikla i zkoumaná nástěnná malba $\mathrm{v}$ Olomouci.

Následujících sedm obrazů představuje sedm bolestí Panny Marie, jež jsou konkrétně spjaty s prolitím Kristovy krve. Stejně jako v sedmi předchozích výjevech je i v těchto akcentována postava Panny Marie, jíž je ve františkánské pašijové mystice přisouzena role přímluvkyně ve smyslu compassio Christi, kdy se snoubí jak Mariina láska, tak její trýzeň při Kristových mukách. Obřezání Krista, prostřednictvím něhož je věrící do cyklu uveden, bylo ve středověku významnou událostí Kristova života, nebot' i přes jeho útlý věk byla poprvé prolita jeho krev, upozorňující na jeho a Mariino budoucí utrpení. Rovněž podstoupení tohoto ritu ukazuje, jako v případě očištování Panny Marie, na Kristovu pokoru, nebot' stejně jako se nemusela očištovat jeho matka, nemusel se ani Kristus jako Pán zákona podřídit zákonu. Obřezání Krista bylo do modlitby sedmi prolití Kristovy krve prvně zařazeno na začátku 15 . století poté, ${ }^{54} k d y$ se postupně zvyšoval počet Ave Maria a Pater Noster v mariánském růženci. Vysvětlení pro zařazení scény Kristus na hoře Olivové do cyklu se nachází v Lukášově evangeliu (Lk 22, 39-46), kde se uvádí, že se Kristus modlil tak horečně, až jeho pot připomínal kapky krve. Na obraze Bičování Krista je již jednoznačně rozpoznatelná krev na jeho těle. Ta je spolu s rukama spoutanýma nad Kristovou hlavou, a tak neskrývanýma před zraky věřících, a s motivem mučení jeho celého těla, jenž je na výjevech Bičování poměrně vzácný, nebot ve většině případů dopadají rány vojáků na jeho horní polovinu, nepochybně prezentována jako Kristova oddanost a věrnost Bohu, kterou si mají uvědomovat i věřící při rozjímání nad scénou, v níž Kristus trpí i za jejich hříchy a konečně i za ně samé. S ním pochopitelně jako v předchozích výjevech soucítí jeho matka, vystavená obdobné, vnitřní bolesti.

Přestože trnová koruna, jejíž ostré trny zarývající se do pokožky na Kristově hlavě způsobily krvácení, měla primárně Spasitele zesměšnit, církevní otcové ji ve scéně Korunováním trním interpretovali jako symbol Kristova triumfu a panování, čemuž by nasvědčovalo i usazení Krista na vyvýšený stupeň nahrazující královský trůn. Výjev Svlékání Krista $z$ roucha, na němž v porovnání s předchozími nedochází $\mathrm{k}$ přímému Kristovu poranění, a tak prolití jeho krve, byl do tohoto cyklu zařazen snad pro upomenutí věřících, nebot' po vysvléknutí Krista $z$ šatů, zakrývajících do té doby jeho tělo, se objevily jeho rány, na něž by se nemělo nikdy zapomínat, ani nejsou-li na první pohled zřejmé. V souvislosti se zobrazením Longina na obraze Ukřižování by se dalo uvažovat o kapkách krve i na šatě Bohorodičky, jak je zmiňováno v Dialogu Anselma s Pannou Marií. Tento námět je

53 Mirella Levi D’Ancona, The Iconography of the Immaculate Conception in the Middle Ages and Early Renaissance, New York 1957, s. 30.

54 Eamon Duffy. The stripping of the Altar:Traditional Religion in England c. 1400 - c. 1580, New Heaven - London 1992, s. 295-296. 
však s ohledem na současný stav svrchních barevných vrstev pouhou domněnkou. Při správnosti tohoto tvrzení by došlo ke zdůraznění Mariiny spoluúčasti na spáse, zatímco mdloby odkazují k jejímu spoluprožívání Kristova utrpení. Ukřižováním jsou zakončena zobrazení sedmi radostí a sedmi bolestí Panny Marie. A přestože jsou jednotlivé výjevy rozděleny do dvou pásů, je mezi nimi souvislost a provázanost, na niž poukazuje i samotný první výjev Zvěstování, jenž je oznámením příchodu Mesiáše Panně Marii, a poslední Ukřižování, kde Kristus svou smrtí otevřel lidem možnost spásy.

\section{Ikonografie - vrchní partie}

Zcela ve vrcholu obrazu jsou znázorněni dva letící andělé nesoucí mohutnou korunu, za níž je vyobrazen iluzivní výklenek s modrou oblohou. Ivo Hlobil, ${ }^{55}$ jehož výklad byl ovlivněn znázorněním holubice Ducha svatého, jež byla následně pro svou nepůvodnost odstraněna, v něm viděl zobrazení porta coeli, jež jako obvyklý mariánský symbol připomíná eschatologickou roli Panny Marie v dějinách spásy. S touto interpretací následně vyslovil svůj nesouhlas Pavol Černý, ${ }^{56}$ jenž výklenek vykládá jako fenestra coeli, ve smyslu Mariiných ctností. Význam rovněž přikládá i znázornění oblohy v tomto výklenku, která dle něj znázorňuje ranní červánky, symbolizující Kristovo početí z Ducha svatého. V souvislosti s podobností olomouckého obrazu s vratislavskou deskou, připomínanou výše, se jeví pravděpodobnější, že i přes nepřítomnost holubice Ducha svatého ve vrcholu obrazu je možné pưlkruhově zakončený výklenek interpretovat jako symbol porta coeli ve smyslu výkladu Ivo Hlobila. To potvrzuje i zobrazení dalších třiceti pěti výjevů na desce $\mathrm{z}$ bernardinského kláštera ve Vratislavi, představujících jak dobré lidské vlastnosti k dosažení nebeského království, tak špatné vlastnosti, jichž by se měli lidé vyvarovat. S tímto výkladem by byla v souladu i závěrečná pasáž textu, publikovaného Antonínem Kalousem, kde jsou vzpomínány odpustky za spásu duše, udělované věřícím za modlitby před obrazem. Spojením výklenku ve smyslu porta coeli a mariánské koruny, znázorněné před ním, by zde Panna Marie byla představena jako Virgo mediatrix. Rozvíjení a šíření této ideje, jež je rovněž spojitelná s druhým veršem 118. žalmu, v němž se uvádí: „Toto je Hospodinova brána, skrze ní vcházejí spravedliví, je od 14. století spjato právě s rádem františkánů.

Celý výjev, situovaný v závěru jižní boční lodi kostela Neposkvrněného početí Panny Marie, je po obvodu lemován pletencovým motivem. V něm Pavol Černý vidí možné zobrazení mnišského cingula jako symbolu mravní čistoty, ${ }^{57} \mathrm{i}$ když pro potvrzení identifikace postrádá detailní zobrazení jeho zakončení. S ohledem na modlitbu mariánského růžence, s níž je celý obraz spjatý, by pletencový motiv mohl představovat trnovou korunu. Ta by tak byla paralelou k věnci $z$ růží, jež zde má podobu jednoduchého růžence z červených a žlutých kuliček, a současně by odkazovala ke Kristovým mukám, znázorněným ve střední partii obrazu. Trnová koruna, vnímaná již od dob církevních otců jako

\footnotetext{
Hlobil (pozn. 5), s. 13.

Černý (pozn. 19), s. 411-412.

Ibidem, s. 413.
} 
symbol chvály a panování Krista, by byla pro věřící příslibem jejich spásy. ${ }^{58}$ Tak by bylo možno trnovou korunu, lemující motiv, vnímat jako očekávání dalšího života v nebi, $\mathrm{k}$ němuž měla věřícím dopomoci i modlitba růžence. Na úzké provázání trnové a růžové koruny ukazuje i anonymní, avšak s dominikánskou variantou růžence spjatý dřevořez z knihy Jacoba Sprengera Erneuerte Rosenkranzbruderschaft z roku 1476, ${ }^{59}$ na němž je Ježíšek na klíně Panny Marie korunovaný trnovou korunou, do níž jsou zasazeny květy, a současně spolu se svou matkou přijímá květinové věnce od členů růžencového bratrstva, modlících se k ústřední dvojici.

\section{Závěr}

Klášterní kostel Neposkvrněného početí Panny Marie a sv. Bernarda Sienského skrývá cenný soubor pozdně gotických nástěnných maleb, jejichž vysoká hodnota je zřejmá již při prvním ohledání. Olomouc, sídlo biskupa, lze ve zkoumané době, tedy přibližně od poloviny 15. století, kdy ji prvně navštívil papežský pověřenec a proslulý kazatel Jan Kapistrán, do dvacátých let 16. století, kdy se i tady začínají prosazovat Lutherovy myšlenky, nepochybně zařadit mezi významná kulturní centra v zemích Koruny české a vzhledem $\mathrm{k}$ historickému dění v inkriminovaném období snad i v celé střední Evropě. Velký podíl na tom měly nepochybně události 15. století, jež je označováno za nejbourrlivější období v dějinách moravského královského města. Díky danému sledu historických událostí si Olomouc potvrdila svou pozici katolického centra, což mělo podíl i na vytvoření podmínek pro vznik a rozvoj specifické kultury.

Dokladem toho je i nástěnná malba v čele klenby závěru jižní boční lodi kostela Neposkvrněného početí Panny Marie a sv. Bernarda Sienského na Bělidlech. Výjev, který je epigraficky datován rokem 1500, je s největší pravděpodobností nejstarším zobrazením Růžencové Madony na našem území. Kromě obvyklých růženců, které drží všechny zobrazené postavy, včetně Ježíška, ve spodním pásu v rukou, je na obraze znázorněn ještě jeden. Růženec v podobě kuliček navlečených na šňůru po celé šířce obrazu obsahuje celkem sedmdesát jedna kuliček, kde je vždy po deseti žlutých vložena jedna červená kulička většího průměru. Tím vzniká sedm částí, k nimž se váže stejný počet zobrazení připomínající sedm radostí a sedm bolestí Panny Marie. Samotný počet kuliček není náhodný, nýbrž číslo sedmdesát jedna vyjadřuje délku pozemského života Panny Marie, jež je na obraze oslavována a které je zde vzdávána úcta.

Z výše uvedeného ikonografického výkladu vyplývá, že ve františkánské verzi růžence je velmi důležitá číslovka sedm. K sedmi částem růžence se váže sedm radostí a sedm bolestí Panny Marie, prostřednictvím nichž jsou připomínány podstatné okamžiky ze života Panny Marie a Krista, tradičních objektů lidové zbožnosti. Sedm je rovněž drahých kamenů na koruně Panny Marie, jež symbolizují jak její vlastnosti, tak její úlohu v dějinách spásy. Sedm výjevů po sedmi je na vratislavské desce s názvem Corona beatisiimae Virginis Marie, jejíchž čtrnáct výjevů ve dvou spodních řadách se zcela shoduje se zobrazeními

58 Jerzy Józef Kopeć, Męka panśka w religijnej kulturze polskiego średniowiecza, Warszawa 1975, s. 249-250.

59500 Jahre Rosenkranz (kat. výst.), Erzbischöfliches Diözesanmuseum Köln 1976, Hatto Küffner Walter Schulten (edd.), Diözesanmuseum Freising 1976, s. 23. 
olomoucké malby a již mohli olomoučtí bratři znát z místa jejího původního uložení, kde se krátce před vznikem olomouckého Růžencového obrazu konala řádová kapitula. Kromě sedmi radostí a sedmi bolestí Panny Marie je zde rovněž vyobrazeno sedm zástupců nebeských hierarchií, personifikace sedmi smrtelných hříchů, sedmi ctností, sedmi darů Ducha svatého a sedmi představitelů pozemského života. Kromě toho jsou všechny tři partie obrazu navzájem propojeny postavou Panny Marie, které je ve františkánském prostředí přisouzena role zprostředkovatelky mezi církví a Kristem. Nebot’ se jedná právě o Pannu Marii, vyvolenou Bohem, zbavenou všech hříchů, jež provázela Krista po celý jeho pozemský život a sdílela s ním všechna jeho utrpení a ponížení, až do jeho smrti na kříži. Po jejím nanebevzetí, jež je posledním zobrazením na olomoucké malbě, pak byla korunována Kristem a Bohem a usedla vedle nich jako královna nebes. Zobrazení Panny Marie jako Virgo mediatrix odpovídá i spojení výklenku ve smyslu porta coeli a mariánské koruny ve vrcholové partii, nebot milosti lze dosáhnout pouze prostřednictvím modliteb a kontemplace před mariánským obrazem.

Z doby po roce 1500 lze na našem území nalézt ještě jednu nástěnnou malbu, jež byla vytvořena dle vratislavské desky. Jedná se o růžencový obraz Koruna Panny Marie nacházející se na západní polovině severní stěny lodi kostela sv. Víta v Jemnici. ${ }^{60} \mathrm{~V}$ současné době můžeme $\mathrm{z}$ původních čtyřiceti devíti medailonů koruny vidět jen několik málo tajemství ve spodní řadě, které připomínají události ze života Ježíše Krista a Panny Marie, jako např́íklad Zvěstování, Navštívení, Narození, Klanění tři králů či Korunování trním. Pro jasnou vizuální a ikonografickou podobnost není pochyb o východisku. S obrazem se mohli bratři seznámit bud při konání jedné z řádových kapitul ve vratislavském klášteře, nebo při pobytu tamtéž, jelikož tam až do roku 1522 sídlilo centrum řádových studií, než došlo k jeho přesunutí do západočeské Kadaně. V jemnickém kostele pak byl prostřednictvím obrazu šíren vizuální formou kult růžencové zbožnosti a malba byla nepochybně používána i jako ilustrace při kázání.

Dobově oblíbené zobrazení Apokalyptické ženy lze rovněž vnímat v souvislosti s interpretací Církve, a to především v návaznosti na kázání Bernarda z Clairvaux na neděli v oktávu svátku Nanebevzetí Panny Marie. ${ }^{61} \mathrm{~V}$ něm vzýval věřící, aby se přimlouvali u Bohorodičky, jíž byla přisouzena role zprostředkovatelky mezi Církví a Kristem, tak jako byl Kristus prostředníkem mezi Bohem Otcem a člověkem. Ve františkánské pašijové mystice je Panně Marii vždy přisouzena role prŕmluvkyně ve smyslu compassio Christi a apokalyptické zobrazení slunce kolem její postavy je patrně možné interpretovat jako naplnění Kristových slov „Já jsem světlo světa“ a dogmatu o Neposkvrněném početí Panny Marie.

Apokalyptické zobrazení sluneční záře kolem postavy Panny Marie, jež patří ve františkánském prostředí mezi oblíbené ikonografické typy, je rovněž možné interpretovat jako naplnění Kristových slov „Já jsem světlo světa“ a myšlenky o Neposkvrněném početí

60 Zuzana Křenková, Die Wandmalerei in der ehemaligen Kirche der Franziskaner-Observanten in Jamnitz und ihr schlesischer Hintergrund, Quart, Kwartalnik Instytutu Historii Sztuki Universytetu Wrocławskiego, 2013, s. 20-35. - Eadem, Nově nalezená malba v bývalém kostele františkánů observantů v Jemnici a její slezské východisko, Památky Vysočiny, sborník NPÚ ÚOP v Telči, 2011, s. 126-39. - Eadem, Středověké dějiny a stavební vývoj kostela sv. Víta v Jemnici, Monumentica IV, č. 1, 2016, s. 18-32.

61 Naposledy zdůraznila výklad Apokalyptické ženy v souvislosti s Bernardovým kázáním Milada Studničková, viz Milada Studničková, Úvodní iluminace Smíškovského graduálu jako klíč k interpretaci rukopisu, in: Dalibor Prix (ed.), Pro arte. Sborník k poctě Ivo Hlobila, Praha 2002, s. 183-189. 
Panny Marie. Dokladem toho je i spis z pera Jan Bosáka Vodňanského Traktát o početí prečistém a neposkvrněném di̊stojné Panny Marie z roku 1509. Na našem území se jedná o jediné dílo, které reflektuje teologický spor, v němž proti sobě stáli na jedné straně františkánští a na druhé straně dominikánští teologové. Traktát je napsán formou dialogu mezi františkánem Janem a jeho odpůrcem, dominikánem Hendrychem. Autor zde na několika místech doporučuje modlitbu k obrazu "panny marie w slunczy“ jako účinnou a spolehlivou. Pravidelnými modlitbami k tomuto mariánskému obrazu se měl dle tradice zázračně uzdravit dokonce i papež Sixtus IV., který byl velkým ctitelem Panny Marie. Díky jeho osobě došlo ke znovuoživení palčivé otázky o Neposkvrněném početí Panny Marie, nebot’ tento pontifik dával své postavení v dané otázce jasně najevo. Např́klad i tím, že zavedl odpustky za modlitbu před obrazem Panny Marie Ve slunci. ${ }^{62}$

S ohledem na ikonografii nástěnné malby v čele klenby závěru jižní boční lodi kostela na Bělidlech, jež jednoznačně reflektuje františkánskou spiritualitu na konci 15. a na počátku 16. století, je nutné hledat objednavatele ve františkánských řadách. Observantský řád byl s ohledem na zachování principu chudoby, který je ustanoven již v jejich řádových regulích, ještě v pozdním středověku stále odkázán při výzdobě svých svatyň na finanční podporu donátorů. Ti tak mohli významně zasáhnout jak do výtvarného programu výzdoby, tak ovlivnit výběr umělců a jejich kvalitu. $S$ ohledem na bohatou a velmi kvalitní výzdobu i jiných klášterních kostelů františkánů-observantů, které byly v pozdním středověku oblíbeným pohřebním místem jejich donátorů, se františkánská prostota a chudoba ocitá v naprostém protikladu k uměleckému vybavení klášterních interiérů a řádových kostelů. Zpravidla se jednalo o mecenáše z řad šlechty či bohatých měštanů, někdy rovněž významné církevní příslušníky. Tomu by v olomouckém prostředí na přelomu 15. a 16. století nejvíce odpovídala postava Jana Filipce. Tento administrátor olomouckého biskupství a kancléř uherského království byl vzdělaný muž, který větší část svého života působil jako poradce Matyáše Korvína a později i jeho následovníka na uherském trůnu, Vladislava II. Jagellonského. Matyáši Korvínovi se Jana Filipce podařilo se souhlasem papeže Sixta IV. dostat i do biskupského úřadu ve Velkém Varadíně, a to i přes skutečnost, že nebyl vysvěcený na kněze. Do františkánského řádu vstoupil Jan Filipec ve Vratislavi v roce 1492 až v pokročilém věku. Dle jeho názorů se jednalo o vytrvalého odpůrce radikální reformace a kritika Jednoty bratrské, jak dokládá i jeho kladné přijetí Svatojakubské smlouvy (1508) namířené proti bratřím. Vedle kláštera v Uherském Hradišti, ${ }^{63}$ který založil roku 1490 a jenž se stal místem jeho posledního odpočinku († 17. června 1498), se podílel na zřízení dvou dalších observantských klášterů, a to v hornouherské Skalici (1469) a ve slezském Javoru (1489).

Po dosazení do čela varadínského biskupství, které bylo jedním z nejbohatších v Uhrách, ${ }^{64}$ se Jan Filipec dostal k dostatečně velkému a pravidelnému př́imu, jenž mu

62 O několik let později zavedl papež Alexandr VI. podobné odpustky za modlitbu před obrazem sv. Anny Samétřetí, viz Stephan Beissel, Rosenkranzbilder aus der Zeit um 1500, Zeitschrift für christliche Kunst 13, 1900, s. 36. Oba dva výše uvedené príílady ukazují na vzrůstající úctu k Neposkvrněnému početí Panny Marie.

63 Patrně pro dobré vztahy s Vladislavem byl klášteru roku 1498 připsán komorní plat z města, čímž byl zabezpečen jeho chod. Josef Macek, Víra a zbožnost jagellonského věku, Praha 2001, s. 215.

64 Podle zprávy jednoho benátského vyslance z roku 1525 vynášelo 26000 zlatých, čímž se řadilo na druhé až třetí místo za ostřihomské arcibiskupství spolu s Pětikostelím. Elemér Mályusz, Egyházi társadalom a középkori Magyarországon, Budapest 1971, s. 181. 
mohl zajistit velmi slušnou obživu, ale i dostatek financí na zakladatelskou a uměnímilovnou činnost. Avšak výnosy z varadínského biskupství musely rovněž pokrýt výdaje na Filipcových diplomatických cestách. A prostředků někdy muselo být opravdu hodně, nebot̉ je známo, že při pobytu ve Francii roku 1487 měl výdaje tak veliké, ${ }^{65}$ že si musel další peníze půjčovat ještě v průběhu cesty. Dle bohatého itineráře Jana Filipce jsme zpraveni o jeho četných cestách do sousedních zemí, včetně slezské Vratislavi, kde ke konci svého života vstoupil roku 1492 do řádu. Navíc je z pramenů doložen pobyt Jana Filipce v inkriminované době v olomouckém klášteře, na jehož opravu po požáru přispíval od roku 1492 a jemuž věnoval několik chorálních knih. ${ }^{66}$ A tak můžeme Růžencový obraz s největší pravděpodobností označit za ztvárnění jeho hluboké mariánské úcty a růžencové zbožnosti, nebot’ se $\mathrm{v}$ jeho osobnosti snoubí činnost donátora, kdy téměř všechny své finance získané $\mathrm{v}$ průběhu světského života postoupil ve prospěch věcí věčných a duchovních, i řádového př́islušníka, díky čemuž skrývá nástěnná malba mnoho rovin, do nichž se lze ponořit pouze při dlouhých úvahách nad životem a utrpením Spasitele a jeho matky Panny Marie.

V souvislosti s přijetím hypotézy, že Jan Filipec byl objednavatelem a ideovým tvůrcem konceptu nástěnných maleb, se znovu otevírá otázka zobrazení skutečných historických postav na nástěnné malbě. Jednalo by se o významné církevní a světské historické osobnosti, se kterými se Jan Filipec setkával na svých četných diplomatických jednáních. Např́klad v letech 1489 až 1490 se odehrála jednání v Linci, ${ }^{67}$ kterých se kromě Jana Filipce zúčastnil jak římský král Maxmilián I., tak papežský legát a další důležité historické postavy tehdejší doby. Při pohledu na nástěnnou malbu se zdá nejvíce pravděpodobné, že Jan Filipec nezůstal jako objednavatel věrným diplomatem Matyáše Korvína, nebot' ten byl dlouhodobě ve válce s římským císařem. Filipec si naopak dovolil být v rozporu s náplní svých dřívějších misí a zpodobnil Friedricha III. i Maxmiliána I. na malbě v olomouckém kostele, a tak jim vzdal hold za podporu při vzniku prvního, papežem oficiálně schváleného růžencového bratrstva. Jana Filipce lze na obraze identifikovat dle zlatého šperku spínajícího plášt', který mu daroval po ukončení jednání v Linci římský král Maxmilián. Tím sám sebe umístil po levici Panny Marie mezi církevní příslušníky, vedle papeže Sixta IV., Heinricha Institorise, Jakoba Sprengera či Jana Kapistrána, již se různými způsoby podíleli na šíření kultu růžencové zbožnosti. Jak dokládá nadace z roku 1492, prostřednictvím níž se udělují stodenní odpustky těm, kdo přijdou zazpívat či poslechnout píseň Salve regina do farního kostela sv. Mořice u prŕležitosti různých církevních svátků, ${ }^{68}$ měl podíl na propagaci mariánského kultu na Olomoucku právě i Jan Filipec.

65 Antonín Kalous, Jan Filipec v diplomatických službách Matyáše Korvína, Časopis Matice moravské CXXV, 2006, s. 3-32, cit. s. 30.

66 S úvahou o Janu Filipcovi jako možném objednavateli nástěnné malby v olomouckém kostele pracoval již dřive Ivo Hlobil, Antonín Kalous či Zuzana Křenková, viz Ivo Hlobil, Úvodní glosy k nástěnné malbě pozdní gotiky a rané renesance na Olomoucku, in: idem - Marek Perůtka (edd.), Od gotiky k renesanci III. Olomoucko, Olomouc 1999, s. 407; Kalous (pozn. 6), s. 42, Křenková (pozn. 59), s. 138.

68 Kalous (pozn. 6), s. 44, pozn. 9. 


\section{LITERATURA A PRAMENY}

\section{Edice a prameny}

Mirella Levi D'Ancona, The Iconography of the Immaculate Conception in the Middle Ages and Early Renaissance, New York 1957.

Philippe Ariès, Dějiny smrti I., Praha 2000.

Bernardino Barban, La corona dei sette gaudi, La Madonna nella spiritualita francescana V, 1963, c. $126-132$.

Stephan Beissel, Geschichte der Verehrung Marias im 16. und 17. Jahrhundert, Freiburg im Breisgau 1910.

František Bolek, Katolické kostely a kaple v Olomouci, Olomouc 1936.

Milan Buben, Encyklopedie řádư, kongregací a řeholních společností katolické církve v českých zemích III/1, Praha 2006.

Josef Cibulka, Korunovaný Assumpta na půlměsíci. Příspěvek k české ikonografii XIV.-XVI. století, in: Jan Štenc (ed.), Sborník k sedmdesátým narozeninám K. B. Mádla, Praha 1929, s. 80-127.

Pavol Černý, Růžencová madona, in: Ivo Hlobil - Marek Perůtka (edd.), Od gotiky k renesanci: výtvarná kultura Moravy a Slezska 1400-1550. III., Olomoucko (kat. výst.), Olomouc 1999, s. 410-413.

Maurice Dejonge, Roma santuario Mariano, Bologna 1970.

Eugène Druve, La méditation universelle de Marie, Maneir, 1949, s. 420-568.

Eamon Duffy, The stripping of the Altar:Traditional Religion in England c. 1400 - c. 1580, New Heaven London 1992.

Petr Ebel, Bohemia Franciscana: Františkánský rád a jeho pưsobení v českých zemích 17. a 18. století, Olomouc 2001.

Jutta Fonrobert, heslo Apokalyptisches Weib, in: Engelbert Kirschbaum (ed.), Lexikon für christlichen Ikonographie I, Freiburg im Breisgau 1994, s. 146.

Rona Goffen, Friar Sixtus IV. and the Sistine Chapel, Renaissance Quarterly XXXIX, 1986, s. 218-262.

Ursula Grossmann, Studien zur Zahlensymbolik des Mittelaters, Zeitschrift für katolische Theologie LXXVI, 1954, s. 19-54.

Petr Hlaváček, Čeští františkáni na přelomu středověku a novověku, Praha 2005.

Ivo Hlobil, K ikonografii, symbolice a významu růžencového obrazu v kostele Neposkvrněného početí Panny Marie v Olomouci-Bělidlech, Sborník památkové péče v Severomoravském kraji I, 1971, 9-16.

Antonín Kalous, Jan Filipec v diplomatických službách Matyáše Korvína, Časopis Matice moravské CXXV, 2006, s. 3-32.

Antonín Kalous, Declaratio brevis Corone immaculate virginis: A source for Late Medieval Popular Piety, Umění LV, 2007, s. 40-44.

Antonín Kalous, Jan Filipec v diplomatických službách Matyáše Korvína, Časopis Matice moravské CXXV,, 2006, s. 3-32.

Karl Joseph Klinkhammer, Adolf von Essen und seine Werke, Frankfurt am Main 1972.

Jerzy Józef Kopeć, Męka panśka w religijnej kulturze polskiego średniowiecza, Warszawa 1975.

Zuzana Křenková, Nově nalezená malba v bývalém kostele františkánů observantů v Jemnici a její slezské východisko, Památky Vysočiny, sborník NPÚ ÚOP v Telči, 2011, s. 126-139.

Zuzana Křenková, Die Wandmalerei in der ehemaligen Kirche der Franziskaner-Observanten in Jamnitz und ihr schlesischer Hintergrund, Quart, Kwartalnik Instytutu Historii Sztuki Universytetu Wrocławskiego, 2013, s. 20-35.

Zuzana Křenková, Středověké dějiny a stavební vývoj kostela sv. Víta v Jemnici, Monumentica IV, č.1, 2016, s. 18-32.

Jules Lutz - Paul Pedrizet (edd.), Speculum humanae salvationis, Leipzig 1907.

Josef Macek, Víra a zbožnost jagellonského věku, Praha 2001.

Elmér Mályusz, Egyházi társadalom a középkori Magyarországon, Budapest 1971.

Heinz Meyer, Die Zahlenallegorese im Mittelater, München 1975.

Adolf Nowask, Církevní památky umèlecké z Olomouce I, Olomouc 1890.

Pieters Frances van den Oudendijk, Dürers „Rosenkranzfest" en de ikonografie der Duitse rozenkransgroepen van de XVe en het begin der XVIe eeuw, Amsterdam 1934.

August Prokop, Aus Olmütz, Mittheilungen $k$. $k$. Central-commission zur Erforschung und Erhaltung der Kunst-und historischen Denkmale, Neue Folge IX, 1883, s. 105-109. 
Philipp Schmidt, Edelsteine, in: Konrad Algermissen - Ludwig Böer - Carl Feckes et al., Lexikon der Marienkunde, Regensburg 1967, col. 1499-1503.

Walter Schulten (edd.), Diözesanmuseum, Freising 1976.

Milada Studničková, Úvodní iluminace Smíškovského graduálu jako klíc k interpretaci rukopisu, in: Dalibor Prix (ed.), Pro arte. Sborník k poctě Ivo Hlobila, Praha 2002, s. 183-189.

Jacobus de Voragine, Legenda Aurea, Praha 1984.

Erich Wimmer, Maria im Leid, Die Mater Dolorosa in der deutschen Literatur und Frömmigkeit des Mittelalters (Dissertation), Philosophische Fakultät Julius-Maximilians-Universität, Würzburg 1968.

Katarzyna Zalewska, Modlitwa i obraz. Średniowieczna ikonografie róźancowa, Warszawa 1999.

\section{MARIAN PIETY AND THE WALL PAINTINGS AT THE CHURCH OF THE IMMACULATE CONCEPTION OF THE VIRGIN MARY AND ST. BERNARDINE OF SIENA IN OLOMOUC}

\section{Summary}

The Late Middle Ages was a time of heightened spirituality and an emphasis on traditional objects of popular piety-the Virgin Mary and the life of Christ. Wall paintings in the choir and at the end of the northern and southern nave of the Church of the Immaculate Conception of the Virgin Mary in Olomouc are surely connected with Marian piety and its expression in the rosary. These trends, which were strongly promoted in Catholic circles, were supported by the mendicant orders and spread through the influence of the Franciscan-Observants.

Among the Franciscans of the 15th century was the most popular version the one that was promoted by St Bernardino of Siena and his disciple St Giovanni of Capistrano. Capistrano was a pale shadow of his master, but his mission in central Europe in the middle of the 15th century had a deep impact on religious life in the region for many decades. His work proved instrumental to the great expansion of power of the Order of Observant Franciscans, and he also played a part in the reawakening of the visual arts in Bohemia after the long years of the Hussite wars. The wall painting of Our Lady of the Rosary from 1500 is a variation on a panel painting of Corona Beatissimae Mariae, now at the National Museum in Warsaw. It was probably the artistic model for the painting in Olomouc. The iconographic programme of the panel, that was created around the year 1500 for the Church of St Bernardino of Siena in Wrocław, was just as a painting in Olomouc a demonstration of the order's reverence for Mary and devotion to the rosary. The fact that paintings were widespread recalls the general trends of piety at the end of the Late Middle Ages, although one can find specific point in common between Franciscans in Olomouc and in Wrocław, Jan Filipec. He was an advisor of the king Matthias Corvinus, an administrator of the Roman Catholic Diocese of Olomouc and from 1492 Franciscan monk He took his vows in Wrocław and joined the Franciscan Order in Olomouc, who he lived about the year 1500 . 


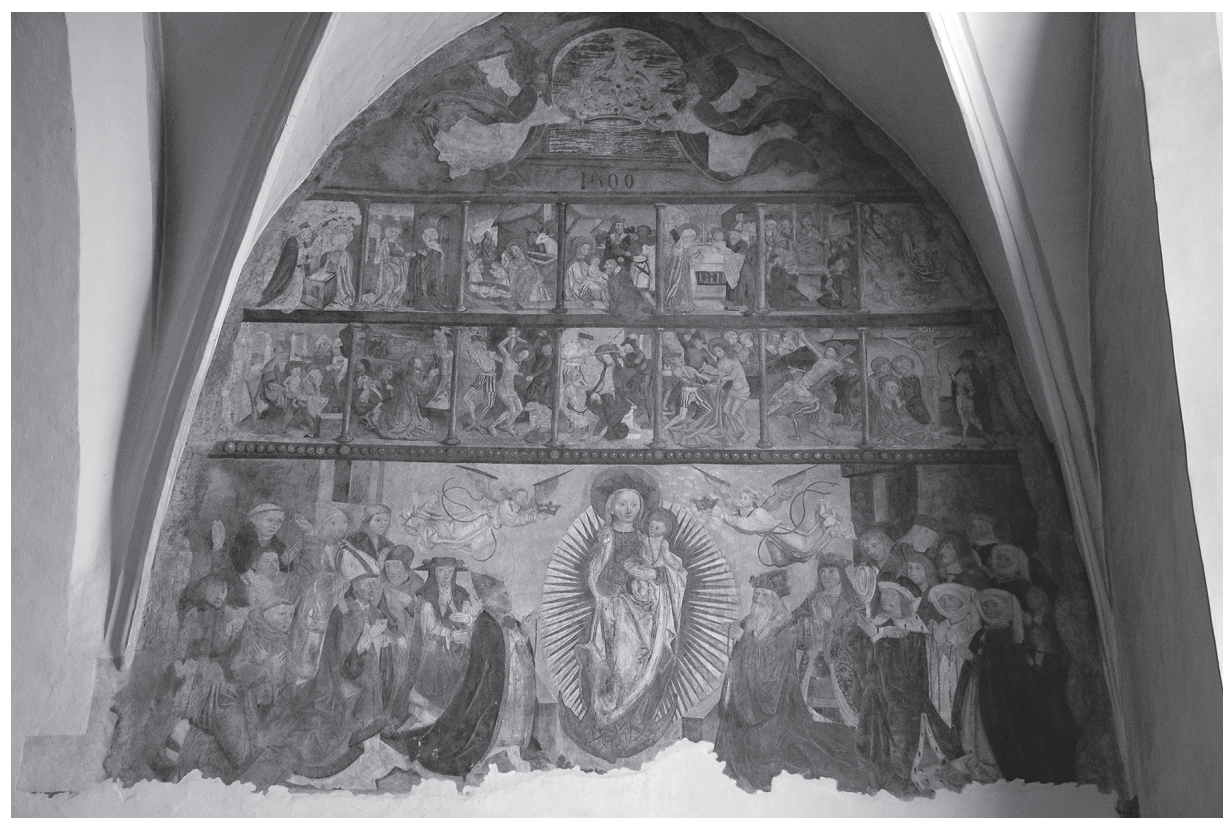

Obrázek 1: Rủžencový obraz, 1500, nástěnná malba, Olomouc, kostel Neposkvrněného početí Panny Marie, závěr jižní boční lodi. Foto: Vladěna Pavlíková

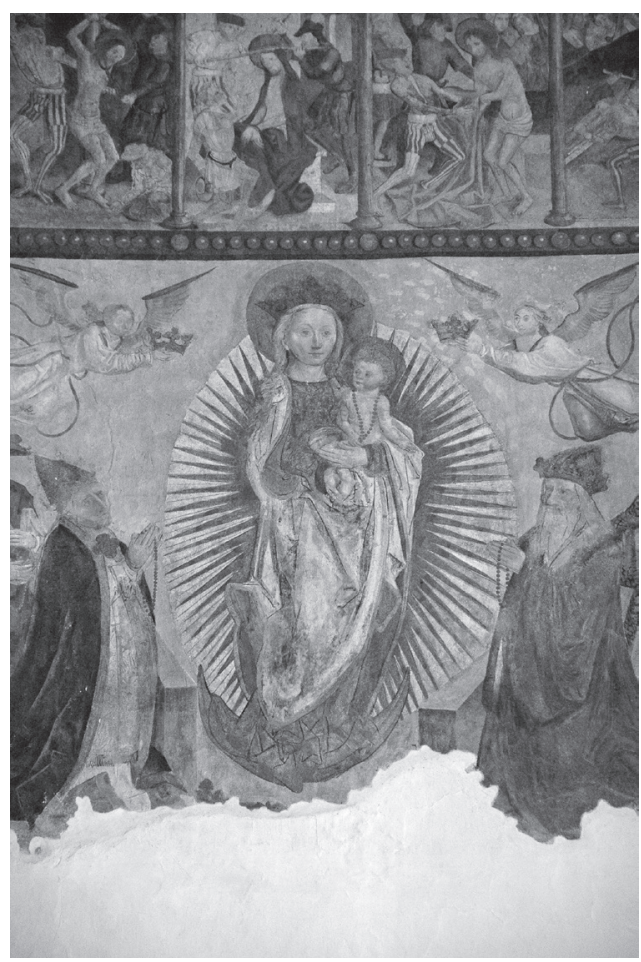

Obrázek 2: Růžencový obraz, detail, 1500, nástěnná malba, Olomouc, kostel Neposkvrněného početí Panny Marie, závěr jižní boční lodi. Foto: Vladěna Pavlíková 


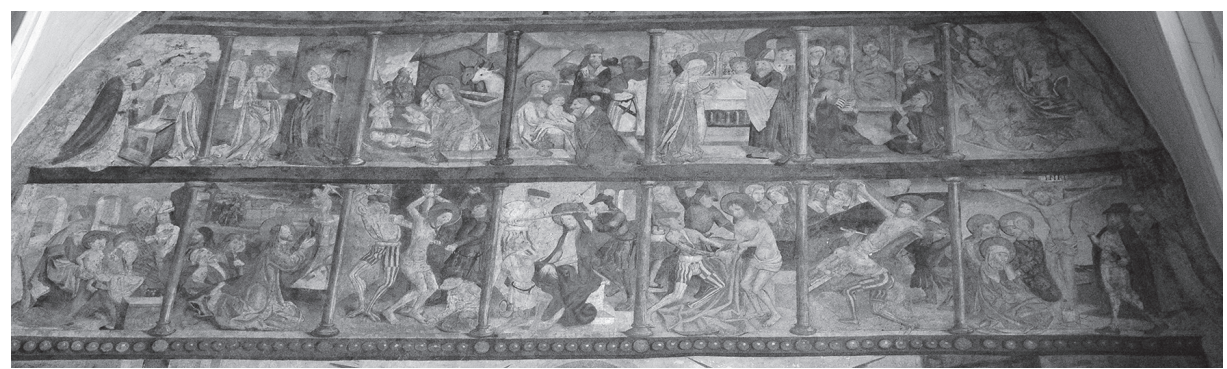

Obrázek 3: Růžencový obraz, detail, 1500, nástěnná malba, Olomouc, kostel Neposkvrněného početí Panny Marie, závěr jižní boční lodi. Foto: Vladěna Pavlíková

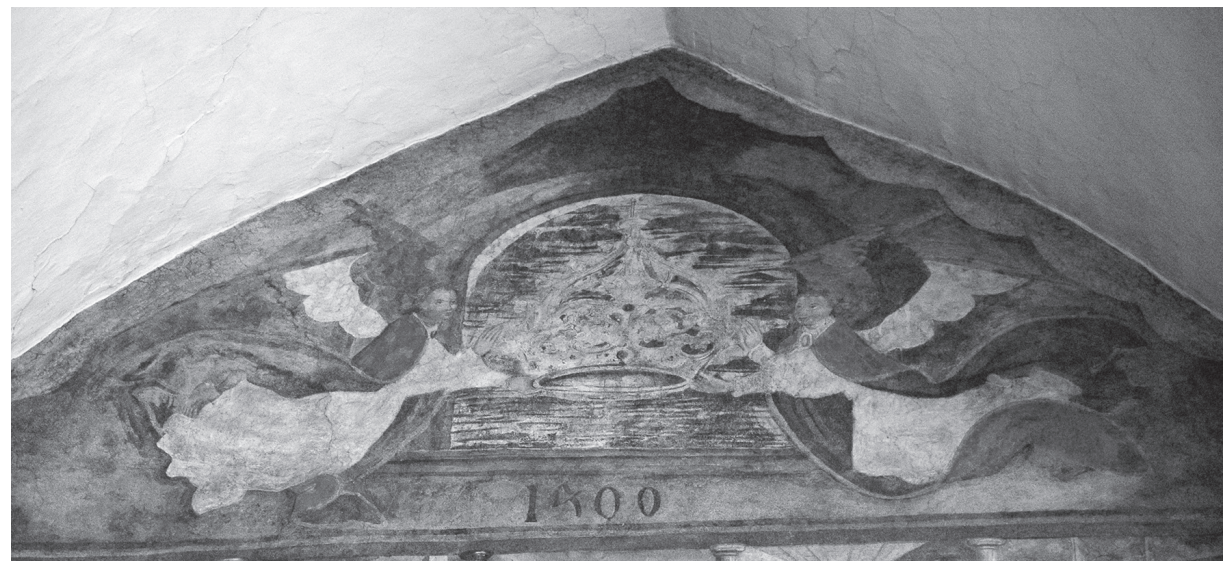

Obrázek 4: Růžencový obraz, detail, 1500, nástěnná malba, Olomouc, kostel Neposkvrněného početí Panny Marie, závěr jižní boční lodi. Foto: Vladěna Pavlíková

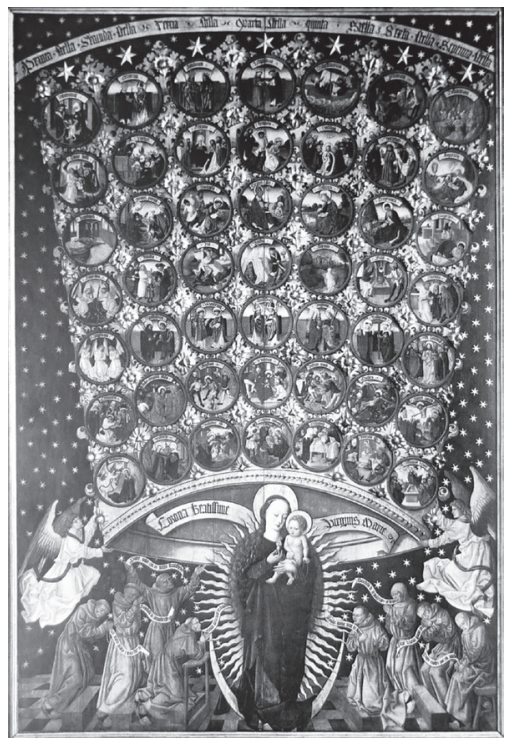

Obrázek 5: Corona beatissimae Virginis Mariae, okolo 1500 , tempera na jedlové desce, Warszawa, Muzeum Narodowe. Reprodukce: Katerzyna Zalewska, Modlitwa i obraz, Średniowieczna ikonografia różańcowa, obr. 12 